\title{
REVIEW OF TESTING METHODS DEDICATED FOR SANDWICH STRUCTURES WITH HONEYCOMB CORE
}

\author{
Arnold Jędral \\ Composite Testing Laboratory, Center of Composite Technologies, \\ Institute of Aviation, al. Krakowska 110/114, 02-256 Warsaw \\ arnold.jedral@ilot.edu.pl
}

\begin{abstract}
This paper is a review of testing methods dedicated for sandwich type composite structures with honeycomb core. First, information about the composition of sandwich materials structures, their properties, types of core materials and applications in the industry is presented. Mechanical properties were compared in the case of different types of the core material. Later, tests methods needed to describe properties of those materials and normalization organizations which create them were mentioned. The testing methods were divided into two groups: mechanical and physicochemical tests. Mechanical properties are: compressive strength (two types of test), edge compressive strength, shear strength (in two directions) and tension strength (two types of test). Physicochemical properties are: material density, water migration, water absorption and thermal conductivity. Testing methods were described according to American Society for Testing and Materials (ASTM) standards. This article is based on professional literature and the author's experience.
\end{abstract}

Keywords: mechanical properties, sandwich panel materials, honeycomb, Kevlar, Nomex.

\section{INTRODUCTION}

Sandwich structures consist of two thin, stiff and strong face sheets called skins and between them is placed light and thick core (honeycomb). The elements are connected by a thin layer of adhesive (Fig. 1). The aim of that structure is to obtain big stiffness and strength in relation to weight.

From a mechanical point of view, sandwich structure materials can be compared to I-beam (Fig. 2). Face sheets play the role of flanges, which means that they carry in-plane compression and tension loads and core carries shear loads as a web in an I-beam. A bond between core and face sheets can be made by applying specific adhesive, which combines all elements into one stiff and strong structure. 


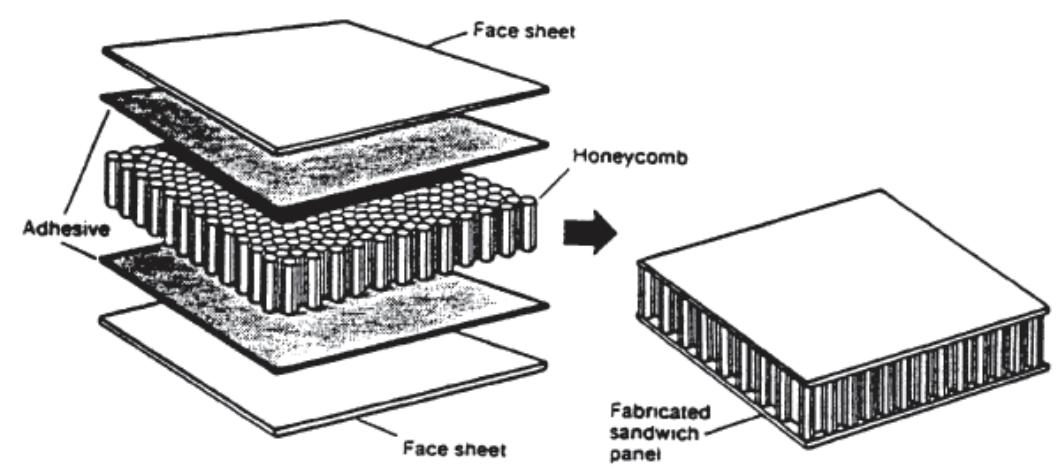

Fig. 1. Honeycomb sandwich panel structure [1]

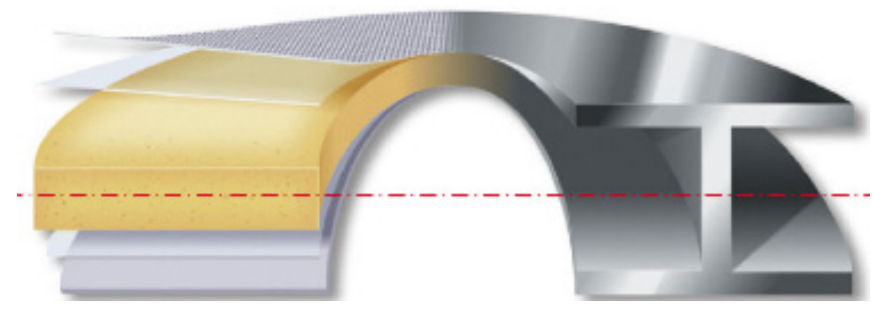

Fig. 2. Sandwich structure panel as an I-beam [2]

Nowadays, sandwich structures can be created by using many different materials. When sandwich structure has to be done, many aspects such as: core type, face sheets material, core material and type of adhesive, have to be considered. Proper choice of all this factors have a huge influence for sandwich structures properties.

Honeycomb market is fast and still growing market which offer various materials for any use. Only Nomex honeycomb market is expected to garner $\$ 383.3$ million by 2021 and register a CAGR (compound annual growth rate) of 8.5\% between 2016 and 2021 [3] (Fig. 3).

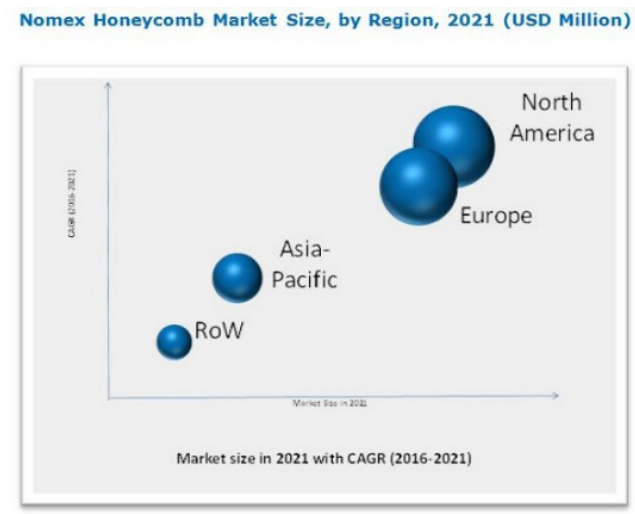

Fig. 3. Growth of Nomex honeycomb market size [3] 
Face sheets can be made of metals (aluminum, stainless steel), composites reinforced with carbon fibers, glass fibers or aramid fibers, plastics, wood or carton $[1,2,4]$.

As a core can be used: foam, honeycomb or natural materials like balsa wood or cork. Foam materials can be plastics like: PVC, PU, PE, PS, PES, PET, PMI, PEI, etc. [4]. It is also possible to use metals in the form of foam but that is not popular because foams have lower strength than honeycombs and lower work temperature (foams: $>180^{\circ} \mathrm{C}$, honeycombs: $>250^{\circ} \mathrm{C}$ ). They are used in elements working on low loads but mostly as an isolating panels.

Honeycomb materials constitute the biggest group of core materials used in sandwich structures. They can be used in form of a metallic and nonmetallic honeycombs. From metallic the most often use is aluminum $(3003,5052,5056)$, which can be applied in structures working in temperature up to $180^{\circ} \mathrm{C}$. Rarely metallic honeycomb is made from steel $(17-\mathrm{PH}, 316 \mathrm{~L}, 347)$, titanium $(6 \mathrm{Al}-4 \mathrm{~V}$, $6 \mathrm{Al}-2 \mathrm{Sn}-4 \mathrm{Zr}-2 \mathrm{Mo})$, lead or copper $[1,2,4,5,6]$. Most commonly they are made from nonmetallic materials. Those could be composite materials reinforced by aramid fiber (Kevlar, Nomex), carbon fiber, glass fiber and plastics (PVC, PET, PEI) [1, 2, 4, 5, 6].

Because of high strength to mass and stiffness to mass ratios, sandwich composite materials are used in aeronautic, cosmonautic and marine industries, sports, transport and many others $[1,2,4,5,6]$. Critical parameter in aviation is mass. Wherever possible, the lightest materials are applied in order to reduce weight of the plane. Exactly for purpose sandwich materials are used. At first, those were mostly secondary structures (failure of that kind of structure does not cause directly a failure of the whole plane), but over the years they were used also in primary structures (Fig. 3).

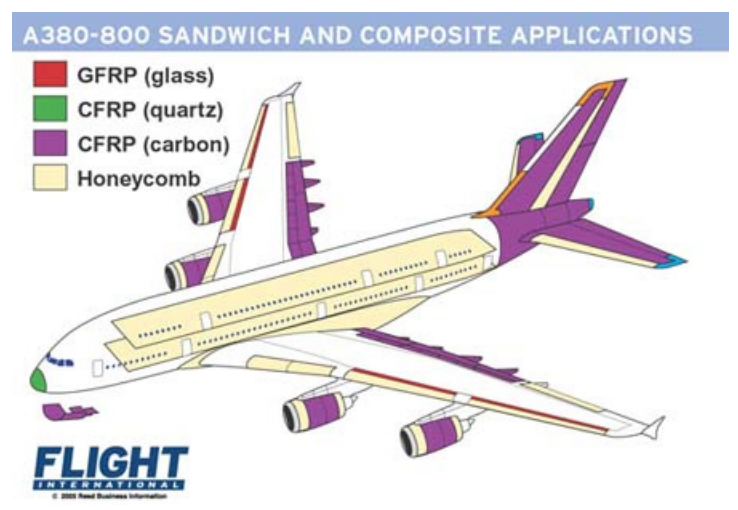

Fig. 4. Application of sandwich materials in Airbus A380 (light yellow color) [7]

Honeycomb core materials are used as: leading edges, trailing edges, flaps, spoilers, cowlings, fuselage, elements inside the plane (floors, ceilings, side panels) [1, 4].

Additionally, in helicopter industry they can be used as the main and tail rotor blades $[1,4]$.

Like in aviation, in cosmonautic industry, mass is a very important parameter. Because of that sandwich panels are so popular there. They are used in many vehicles as flaps, external panels of the body, leading edges, radar covers, in telescopes, drones, antennas, space stations [1, 4].

Sandwich materials are widely used in marine industry, for example in boats, ships, yachts, motorboats building or as elements of docks in marinas. They are usually used in interiors of ships as a hull, hatches, claps, platforms, etc. [1, 4, 8]. 
The wide use of these materials has made them very common in everyday life. Nowadays sandwich materials play a very important role in many industries and everyday life. Of all the above mentioned types of cores, honeycombs are the most commonly and widely used.

\section{SANDWICH MATERIALS TEST METHODS}

To be sure that composite material meets the expectations, it has to be thoroughly investigated before it is certified. Every material has its specific properties and on the basis of them, it is designed to work in different environments. Sandwich materials test methods are based on two main categories: mechanical tests and physicochemical tests.

Nowadays, many standards exist that describe how to evaluate properties of composite materials. It can be American Section of the International Association for Testing Materials standards (ASTM), international standards (ISO), United States military standards (MIL-STD), aerospace material standards (AMS) and own standards of the biggest production companies such as: Boeing (BMS), McDonnell Douglas (MMS) etc. [9-12]. Each of those standards leads to achieving comparable values of a measured unit. To unify the content of the paper, all described test methods will be based on ASTM standards.

\subsection{Physicochemical properties of honeycomb}

Properties of bare core strongly correspond with properties of the whole sandwich structure. Because of that it is important to test its properties in the first place and then properties of core and skins. Physicochemical tests refer mainly to cores.

\subsubsection{Core density}

Honeycomb producers treat core density test as a basic control tool after production. Frequently, mechanical properties of honeycomb cores are proportional to their density. According to American standards, core density can be evaluated using ASTM C271 [13].

This test is not complicated and do not require any special devices. Tests should be performed under sterile condition at room temperature. According to ASTM standard, minimal dimensions of the sample are $300 \times 300 \mathrm{~mm}$, although others are also acceptable. Height of the sample can be the same as honeycomb sheet from which it was cut. Before measurements, samples has to be dry in case to decrease to minimum environmental factors such as humidity. Drying in $50^{\circ} \mathrm{C}$ for $2 \mathrm{~h}$ is adequate to make them dry. Measurement of thickness, width and length shall be performed using caliper and micrometer. Next step is to weigh the sample. Core density can be calculated by putting all the measured dimensions into equation (1):

$$
d=\frac{1000000 W}{l w t}
$$

where: $d$-density $\left[\mathrm{kg} / \mathrm{m}^{3}\right], W$ - weight $[\mathrm{g}], l$ - length $[\mathrm{mm}], w$ - width $[\mathrm{mm}], t$ - thickness $[\mathrm{mm}]$. 
According to this test, it is possible to define density of newly manufactured materials or check authenticity of data from producers in case of whatever suspicions about some defects may arise.

After measurements, it is possible to use the same samples to check cell size, thickness of the wall and node. Those are additional information that could be useful in properties comparison of the same type of materials.

Assuming constant cell size, honeycomb with density around $40 \mathrm{~kg} / \mathrm{m}^{3}$ will have compression strength around 1.5 MPa and honeycomb with $72 \mathrm{~kg} / \mathrm{m}^{3}$ density - $4 \mathrm{MPa}$ compression strength, which means the higher density has honeycomb the higher strength it will has.

\subsubsection{Water absorption}

Water inside sandwich materials is highly undesirable. It causes decrease in strength, Young modulus, change dielectric constant, etc. As a result, all sandwich structures are designed and made in such a way so as to collect minimum of water inside the cells and to gain minimum amount through the skin. Water absorption can be determined according to ASTM C272 [14].

Testing samples have the dimensions of $75 \times 7 \times 12.5 \mathrm{~mm}$. The first step is to dry and then weigh them with the highest possible accuracy. The next step is humidity treatment. According to ASTM C272 evaluation of water absorption can be achieved in three ways.

The first method is to dip the sample in distilled or deionized water at $23 \pm 3^{\circ} \mathrm{C}$ for $24 \mathrm{~h}$. After that time take off the sample from water, shake it (sometime water will remain in cells - especially if they have a small size), wipe off of dripping water and weigh it.

The second method is to place a sample in a humid environment for 30 days. It can be an environmental chamber with, for example, $70 \pm 3^{\circ} \mathrm{C}$ and $85 \pm 5 \%$ humidity. After 30 days, take off the sample from the chamber and weigh it.

The third method is to dip a sample in water at $23 \pm 3^{\circ} \mathrm{C}$ for $48 \mathrm{~h}$. After that time, take it out of water, shake it, wipe it off, dip in isopropyl alcohol, take it out of alcohol, shake again, wait until alcohol evaporates and finally weigh it. Then, dip the sample again in water for $48 \mathrm{~h}$ and repeat all the above steps until gain in weight will be less than $2 \%$ between consecutive weightings.

Water absorption can be calculated according to equation (2):

$$
\%=\frac{W-D}{D} \times 100
$$

where: $W$ - weight of the sample after dipping in water / placing in environmental chamber, $D$ - weight of dry sample.

\subsubsection{Water migration}

Presence of water in sandwich structures was mentioned in the previous chapter. But sometimes it happened that water remained inside the structure. The aim of water migration test is to determine how easily water can get inside the material. To determine water absorption in honeycomb core structures, ASTM F1645 standard is useful [15].

Samples for water absorption test have the dimensions of $127 \times 127 \times 12.7 \mathrm{~mm}$ (core) and thin skins of around $2 \mathrm{~mm}$. A sample structure is made with honeycomb core, transparent skins (for example, 
PMMA) and a layer of adhesive between skin and core. Skins should be transparent but that is not necessary. That kind of skins will make observation of migrating water much easier. Adding pigment into water will additionally increase water observations. The only requirement for the adhesive to which the materials are combined is its resistance to water.

At the beginning of the test, a small hole in one of the skins should be drilled through the thickness. The diameter of the hole should not be bigger than honeycomb cell diameter. Drilling has to be done very precisely so as not to break cell walls. Destroyed walls will cause easier water migration inside the sample. This hole should be placed in the center of the sample. The next step is to define the amount of water needed to fill one cell. To do that it is necessary to weigh the sample before filling one cell with water and then weigh it with distilled water. The last step is connection sample with burette containing water. This connection will provide constant source of water going into the sample during test. A source of water should be at a height of $1 \mathrm{~m}$ approximately (Fig. 4). The place where burette touches the hole can be filled with adhesive or rubber to prevent water from leaking out. Leave prepared setup for $24 \mathrm{~h}$ in room temperature. After that time, check water transfused into the sample by weighing the sample or reading from burette scale $[1,15]$.

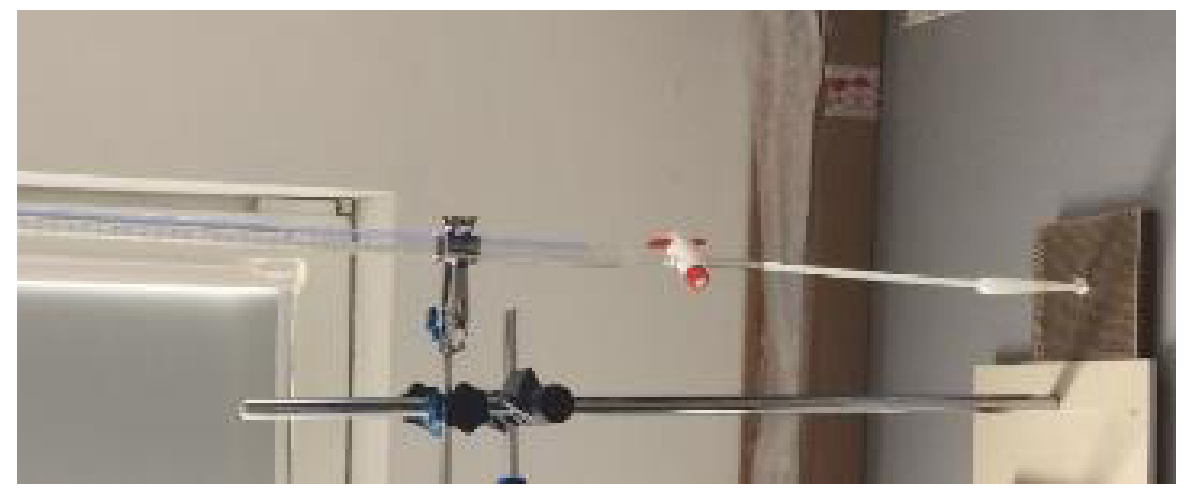

Fig. 5. Water migration test according to ASTM F1645 [AJ, 2017]2.1.4. Thermal conductivity of honeycomb

Thermal conductivity is an important property of honeycomb materials. Depending on the material application, it is required to be an insulator or a conductor. When high conductivity is required in the structure then metal honeycombs (aluminum, steel) are preferred. When low - nonmetallic materials (Nomex, Kevlar, glass fiber, plastics). How to measure honeycomb thermal conductivity is described by C518 ASTM standard [16].

Thermal conductivity test consists on measurement of heat flow through the sample. Sample need to be placed between two metal plates which one of them is hot and another one is cold (Fig. 5). Before the test samples need to be dry. During the test, heat moves from the hot plate to the cold one through the sample. Thermal conductivity is calculated according to formula (3):

$$
k_{H C}=k_{T} \frac{t_{H C}}{t_{T}}
$$

where: $k_{H C}$ - honeycomb thermal conductivity, $k_{T}-$ measured thermal conductivity, $t_{H C}-$ core thickness, $t_{T}$-sample thickness. 


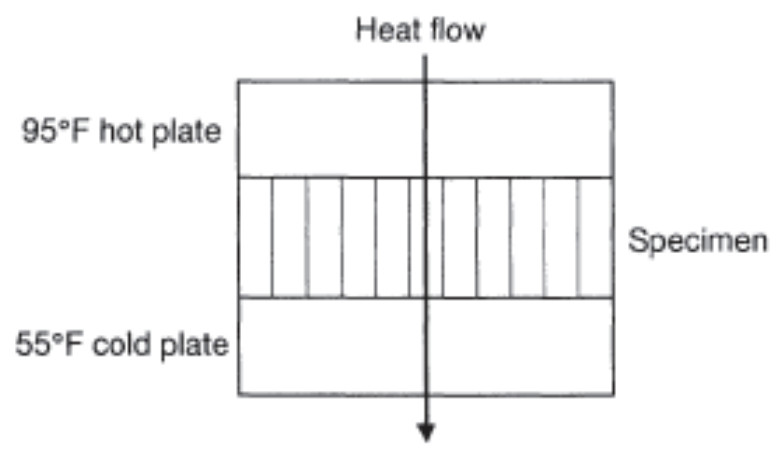

Fig. 6. Scheme of thermal conductivity test [1]

For nonmetallic honeycombs thermal conductivity depends mostly on cell size and for metallic honeycombs on density [1].

\subsubsection{Corrosion resistance of honeycomb}

Structures made from nonmetallic honeycombs do not corrode. An opposite situation takes place when honeycomb is made from metal. To investigate influence of corrosion mass loss of sample that is exposed to corrosive environment has to be evaluated. ASTM B117 standard is dedicated to do this test [17].

The test consists on placing samples in a special chamber where they are subjected to a corrosive environment. Usually, it happens due to an action of fumes of dissolved sodium chloride in water. Solution used for the experiment should have $\mathrm{pH}$ in a range of 6.5-7.2. A sample with the dimensions of $127 \times 152 \times 15.9 \mathrm{~mm}$ is placed in a chamber for at least $48 \mathrm{~h}$ (before that, a sample has to be weighed) at $35 \pm 2^{\circ} \mathrm{C}$. After that time, the sample is taken out of the chamber and weighed. Weight loss less than $1.345 \mathrm{~g} / \mathrm{m}^{2}$ is considered as a positive result for aluminum honeycomb.

\subsection{Mechanical properties of honeycomb}

Mechanical properties are the most important properties of materials used in any construction. Based on them it is possible to find an adequate application of the material.

Sandwich structures with honeycomb core are anisotropic. This applies mainly to a core which presents different properties in L and W direction (Fig. 6).

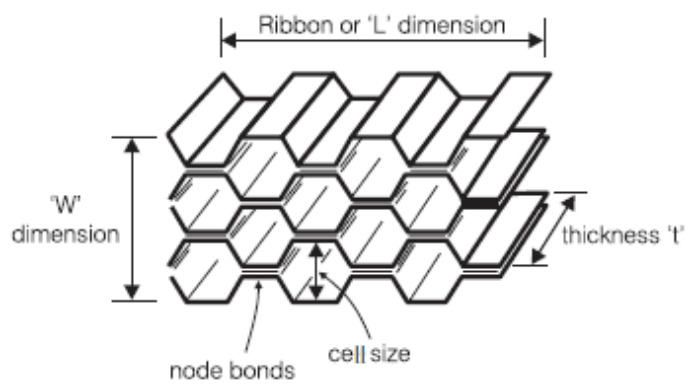

Fig. 7. Honeycomb structure [5] 
Because of that, some properties (shear strength and tensile strength) are tested in both directions. Due to the fact that during production, cells in W direction are bonded by the adhesive (see node bonds in Fig. 6), strength here is lower than in L direction.

\subsubsection{Shear strength of honeycomb}

Shear strength is one of the most important properties for honeycombs. It provides information about the maximum shear strength and shear modulus (Kirchhoff modulus). Those properties are extremely important during design of elements made by sandwich materials.

The test can be carried out in accordance with ASTM C273 in two variants [18]. The first one is shear strength obtained by compression of the core, the second one by tension. In both cases, samples have the same dimensions, the way of loading the sample differs. It is possible to test only cores themselves or cores with skins (sandwich structures).

Samples with the width of not less than $50 \mathrm{~mm}$ and the length of not less than 12 times in thickness (usually $12.7 \mathrm{~mm}$ ), have to be bonded to metal plates, through which shear loads are carried out. Depending on core orientation, it is possible to obtain shear strength in L or W direction. An important thing is to load a sample in such a way that stress axis passes from one corner to another, diagonally opposite (Fig. 7).

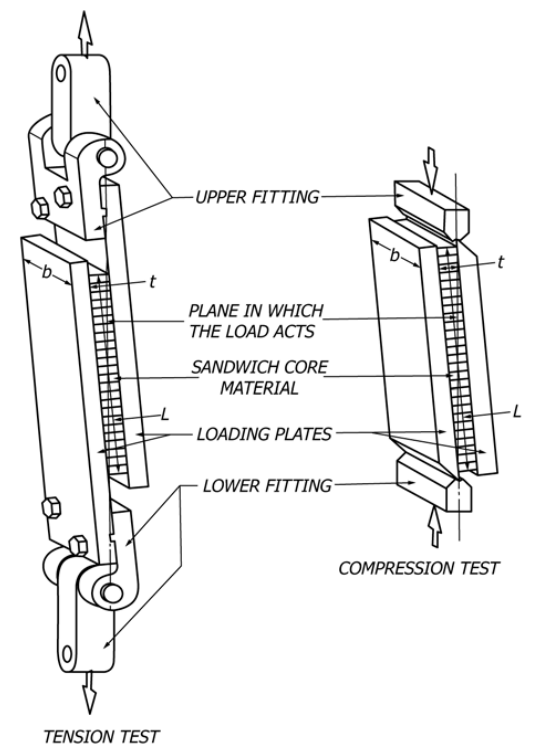

Fig. 8. Loading modes according to ASTM C273 [18]

According to ASTM C393, shear strength can be obtained in one more way [19]. This method based on three or four-point bending test. It is suitable for dense cores (above $160 \mathrm{~kg} / \mathrm{m}^{3}$ ) [1]. Honeycomb with the dimensions of $76 \times 203 \times 12.7 \mathrm{~mm}$ is bonded to aluminum skins (composite skins are also suitable), then during the test bending occurs which causes local shear load inside the sample. In three-point bending mode, support spacing should be $152 \mathrm{~mm}$. Additionally between the sample and the support, a rubber pad has to be placed to prevent the local sample from crushing. This method 
is much more suitable for the whole sandwich structures (core + skin) than bare cores. To determine shear strength of honeycomb from this method it is necessary to know stiffness of skins material which is not easy.

\subsubsection{Tensile strength (flatwise tensile test)}

The test should be carried out in accordance with ASTM C297 [20]. Bare honeycombs (without skins) or sandwich structure can be tested. In accordance with ASTM standard, a sample should have the dimensions of $12.7 \times 50.8 \times 50.8$ millimeters. In the first order, a sample has to be bonded to metal blocks through which tensile loads are transferred into the sample. Surface preparation is of great importance. When bare honeycomb is tested, its surface does not need any special treatment. Cleaning with dry cloth should be sufficient. Honeycomb with skins can be prepared in two ways. The first one is hand grinding with sandpaper. The second is sandblasting. Sandblasting needs different pressure in different materials. For example, when skin is made by carbon fiber composite, 3 bars should be satisfactory. When skins is metal (aluminum or steel) it should be about 6-7 bars. After grinding or sandblasting surface should be cleaned by acetone to remove remaining material. It is important to have good quality adhesive between blocks and a sample because without that, it will be impossible to destroy the sample. An example of a sample in testing fixture is shown in Figure 8.

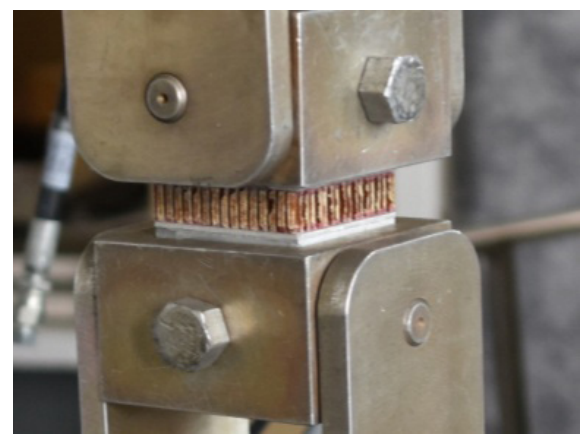

Fig. 9. Sample in testing fixture [AJ, 2017]

There are 4 types of failure in flatwise tensile test: core failure, adhesive failure of core-facing adhesive, cohesive failure of core-facing adhesive and skin failure. Adhesive failure occurs when adhesive remains only on one bonded surface. It can mean wrong surface preparation. Cohesive failure takes place when adhesive remains on both bonded surfaces, it means that during test maximum tensile strength of adhesive have been achieved. Skin failure occurs when maximum tensile strength of skin have been achieved. In general, the only acceptable failure mode is core failure because only this situation gives information about core strength.

\subsubsection{Tensile strength (node tensile strength)}

Node tensile strength test is useful for honeycomb producers. In this test, connection between cells is determined (see node bond in Fig. 6). According to that test, it can be checked if during honeycomb processing (cutting, bending, etc.) node bond can be destroyed. 
The test should be carried out in accordance with ASTM C363 [21]. A sample with the dimensions of $130 \times 260 \times 12.7 \mathrm{~mm}$ is placed in fixture and tensile loads are applied in perpendicular to node bond direction. The sample is placed in fixture by loosely set pins through honeycomb cell (Fig. 9). The only acceptable failure mode is when node bond between cells is destroyed. Node tensile strength is calculated as a force to cross-section area ratio.

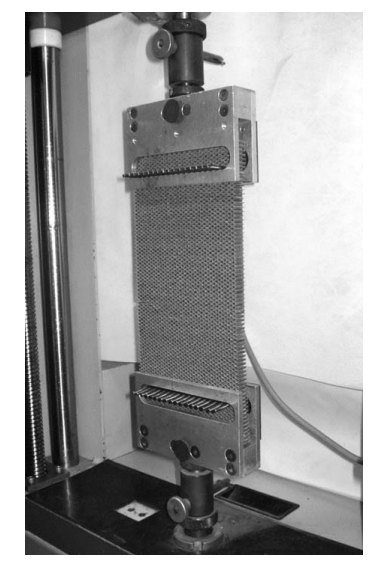

Fig. 10. Sample during test according to ASTM C363 [21]

\subsubsection{Edgewise compressive strength}

Edgewise compressive test is dedicated mostly for sandwich panels, rather than for bare honeycombs. During that test, compressive loads are carried out by skins and the role of core is to keep them together and reduce bending effect. The test should be carried out in accordance with ASTM C364 [22]. Samples usually have the dimensions of $50 \times 50 \times 12.7 \mathrm{~mm}$. Preparation of side edges of a sample in this test is very important. They have to be parallel to each other to avoid differences in loads. A sample is placed in fixture shown in Figure 10 and with fixture, between compressive platens. Edgewise compressive strength is calculated as the quotient of force and area of both face sheets.

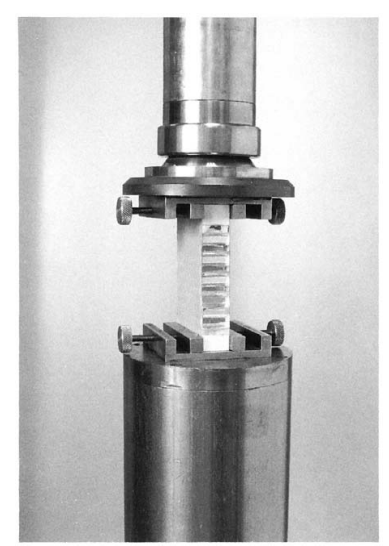

Fig. 11. Sample during test according to ASTM C364 [22] 


\subsubsection{Compressive strength}

Compressive strength is second most important test of honeycomb materials. The tests are carried out in accordance with ASTM C365 [23]. There are two types of compressive strength tests: bare compression test and stabilized compression test (for sandwich panels).

In the first type, samples have the dimensions of $76.2 \times 76.2 \times 15.9 \mathrm{~mm}$ for aluminum core or $12.7 \mathrm{~mm}$ for nonmetallic core. A sample is placed between metal plates and compressed with a loading speed of $0.5 \mathrm{~mm} / \mathrm{min}$ (Fig. 11). In the second type samples have aluminum skin bonded to core. Skin should have thickness in a range of $0.5-1 \mathrm{~mm}$. Skins provide better maintain core cells in the same position during compression and thus more accurate compressive strength of honeycomb. In this test it is possible to determine honeycomb compressive strength and compressive modulus if suitable devices were used (extensometers or deflectometers).

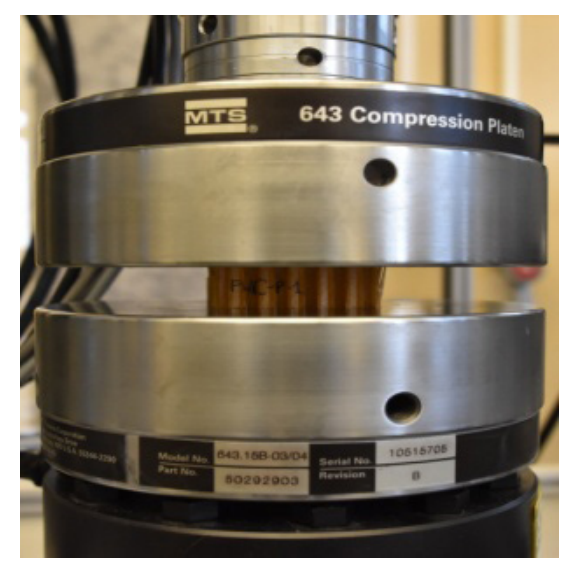

Fig. 12. Sample during test according to ASTM C365 [AJ, 2017]

\subsubsection{Fatigue shear strength}

Fatigue shear strength according to ASTM C394 [24] is an extension of ASTM C273. During this, a test sample undergoes a cyclic shear load simulating the fatigue strength of the material. Sample dimensions and test fixture is the same as in ASTM C273. An important thing is that while in the shear test bare honeycomb can be tested or honeycomb with skins, in fatigue test sample cannot have skins. It has to be directly attached to metal plates.

During the test, a sample is subjected to a shear load for a specified number of cycles. The result is the maximum force at which failure occurs and the number of cycles after which this happened.

\section{CONCLUSIONS}

Based on a review of honeycomb test methods, the following conclusions were made:

1. Honeycomb core structures are well known nowadays and played important role in human life.

2. Because of high strength to mass and stiffness to mass ratios, honeycomb core materials are used in many industries (aeronautic, cosmic, military, transportation, sports, marine).

3. In aviation they mostly are used as a material in secondary structures such as floor and wall panels, trailing edges, flaps, spoilers and cowlings. 
4. Over the years honeycomb core structures have become more and more important in aviation industry so they started to be used in primary structures, helicopter rotor blades for example.

5. Sandwich panel structures can be divided into two groups: materials with artificial core (foams or honeycombs structure) and materials with natural core (balsa wood, cork, etc.).

6. Among the honeycomb structures, materials with artificial origin are most often used (glass fiber, aramid fiber, aluminum alloys) due to low cost and high mechanical properties.

7. Honeycomb market is fast and still growing market which is expected to get $\$ 383.3$ million in next few years and register a CAGR (compound annual growth rate) of 9.6\% between 2016-2021 (for Nomex honeycomb materials).

8. There are many normalization organizations (i.e. ASTM, ISO, MIL-STD, AMS, BMS) which define quality requirements for sandwich materials.

9. Design of structures with honeycomb core materials, requires determination of their physicochemical and mechanical properties.

10. From a mechanical point of view, sandwich structure materials can be compared to I-beam where sheets play the role of flanges and core is a web.

11. Due to the structure, these materials are anisotropic and have different properties in different directions, shear strength in $\mathrm{W}$ direction is almost twice lower than in L direction (e.g. Nomex has 1.25 $\mathrm{MPa}$ in $\mathrm{L}$ direction and 0.6 $\mathrm{MPa}$ in $\mathrm{W}$ direction).

12. Physical and chemical properties which have to be consider in design stage of component are: water migration, material density, cell size, thermal conductivity.

13. Mechanical properties include: compressive strength, shear strength (in two directions), node tensile strength, flatwise tensile strength, edge compressive strength and fatigue tests.

14. Mechanical strength of these materials depends on three parameters: type of material, cell size, material density (number of fibers and resin).

14.1. Strength of honeycomb becomes higher with higher density - for honeycomb with $40 \mathrm{~kg} / \mathrm{m}^{3}$ density, compressive strength is $1.5 \mathrm{MPa}$, and for honeycomb with $72 \mathrm{~kg} / \mathrm{m}^{3}$ density $-4 \mathrm{MPa}$ shear strength.

14.2. Strength of honeycomb becomes smaller with a larger cell size - for honeycomb with $3.2 \mathrm{~mm}$ cell size, shear strength in L direction reached $1.9 \mathrm{MPa}$, and for $4.8 \mathrm{~mm}$ cell size $-1.6 \mathrm{MPa}$ shear strength.

14.3. Different strength resulting from the type of honeycomb material: Nomex $-5.1 \mathrm{MPa}$ shear strength, aluminum - 4.96 MPa, PC - 2.2 MPa.

\section{BIBLIOGRAPHY}

[1] Bitzer T., 1997, "Honeycomb technology. Materials, design, manufacturing, applications and testing", Springer-Science+Buisness Media, B.V.

[2] DIAB Core Guide Rev 1, December 2012.

[3] Nomex Honeycomb Market by Application (Aerospace \& Defense, Transportation, Sporting Goods and Others), Aerospace \& Defense, Sub Application (Interior and Exterior), and by Region - Global Forecasts to 2021, 09.10.2018, from http://www.marketsandmarkets.com/Market-Reports/nomex-honeycomb-market-197303057.html

[4] CMH-17-6, 2013, Composite Materials Handbook, Volume 6 - Structural Sandwich Composites.

[5] HexWeb Honeycomb Attributes and Properties, A comprehensive guide to standard Hexcel honeycomb materials, configurations, and mechanical properties, 1999. 
[6] Plascore Honeycomb Core For Commercial, Defense and Space Applications, 2015.

[7] Composites Symposium 2011, 10.07.2017, from http://www.euroaviasevilla.es/compositesymposium/why_composites.php

[8] Wiśniowski W., 2014, „Twenty Years of Light Aircraft and Safety Program”(„XX lat programu samolotów lekkich i bezpieczeństwa (PSLIB)", Transactions of the Institute of Aviation, No. 3(236), pp. 7-25 (in Polish).

[9] International Organization for Standardization, 10.08.2017, from https://www.iso.org

[10] ASTM International, 01.09.2017, from https://www.astm.org

[11] SAE International, 01.09.2017, from http://standards.sae.org

[12] BMS Specification Revision Index, 01.09.2017, from http://active.boeing.com/doingbiz/d14426/ index.cfm

[13] American Society for Testing and Materials, 2016, "Standard Test Method for Density of Sandwich Core Materials", ASTM C271/C271M-16.

[14] American Society for Testing and Materials, 2001, "Standard Test Method for Water Absorption of Core Materials for Sandwich Constructions", ASTM C272-01.

[15] American Society for Testing and Materials, 2005, "Standard Test Method for Water Migration in Honeycomb Core Materials”, ASTM F1645-00.

[16] American Society for Testing and Materials, 1998, "Standard Test Method for Steady-State Thermal Transmission Properties by Mean of the Heat Flow Meter Apparatus", ASTM C518-98.

[17] American Society for Testing and Materials, 2011, "Standard Practice for Operating Salt Spray (Fog) Apparatus". ASTM B117-11.

[18] American Society for Testing and Materials, 2011, "Standard Test Method for Shear Properties of Sandwich Core Materials", ASTM C273/C273M-11.

[19] American Society for Testing and Materials, 2011, "Standard Test Method for Core Shear Properties of Sandwich Constructions by Beam Flexure”, ASTM C393/C393M-11.

[20] American Society for Testing and Materials, 2016, "Standard Test Method for Flatwise Tensile Strength of Sandwich Constructions”, ASTM C297/C297M -16.

[21] American Society for Testing and Materials, 2009, "Standard Test Method for Node Tensile Strength of Honeycomb Core Materials”, ASTM C363/C363M-09.

[22] American Society for Testing and Materials, 1999, "Standard Test Method for Edgewise Compressive Strength of Sandwich Constructions', ASTM C364-99.

[23] American Society for Testing and Materials, 2000, "Standard Test Method for Flatwise Compressive Properties of Sandwich Cores", ASTM C365-00.

[24] American Society for Testing and Materials, 2000, "Standard Test Method for Shear Fatigue of Sandwich Core Materials", ASTM C394-00. 


\section{PRZEGLĄD METOD BADAWCZYCH DEDYKOWANYCH MATERIAŁOM PRZEKŁADKOWYM Z WYPEŁNIACZEM TYPU HONEYCOMB}

\section{Streszczenie}

Niniejszy artykuł jest przeglądem metod badawczych przeznaczonych do charakteryzacji materiałów przekładkowych z wypełniaczem typu plaster miodu (honeycomb). Na wstępnie zawarto informacje o budowie materiałów przekładkowych, ich właściwościach, podziale ze względu na rodzaj materiału wypełniacza, a także zastosowaniu w różnych gałęziach przemysłu. Porównane zostały właściwości wytrzymałościowe tych struktur w zależności od rodzaju materiału wypełniacza. W dalszej części wymienione zostały metody badawcze potrzebne do charakteryzacji materiałów typu honeycomb oraz organizacje normalizacyjne określające te metody. Zostały one podzielone na dwie kategorie: metody określające właściwości mechaniczne oraz właściwości fizyczno-chemiczne. Do właściwości mechanicznych należą: wytrzymałość na ściskanie (dwa rodzaje), ściskanie krawędziowe, ścinanie (w dwóch kierunkach) oraz rozciąganie (dwa rodzaje). Do właściwości fizyczno-chemicznych należą: gęstość materiału, absorpcja wody, migracja wody, a także przewodnictwo cieplne. Metody badawcze zostały opisane w oparciu o normy ASTM (American Society for Testing and Materials). Przedstawione informacje opierają się na literaturze fachowej oraz na doświadczeniu autora.

Słowa kluczowe: właściwości mechaniczne, materiały przekładkowe, honeycomb, Kevlar, Nomex. 